\title{
PENGLIBATAN SOSIAL DAN PEMBUDAYAAN NILAI MURNI MELALUI PEMBELAJARAN TIDAK FORMAL DALAM KALANGAN PENDUDUK BANDAR PUTRAJAYA
}

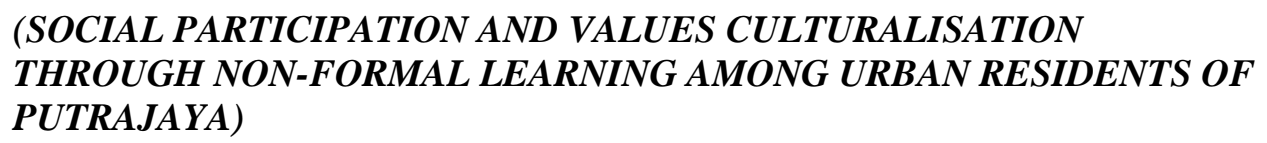

\author{
Abdul Aziz Rahman', Abdul Razaq Ahmad ${ }^{1 *}$, Jalaluddin Abdul Malek ${ }^{2}$ and \\ Mohd Mahzan Awang ${ }^{1}$
}

${ }^{1}$ Faculty of Education,

${ }^{2}$ Faculty of Social Science and Humanities,

Universiti Kebangsaan Malaysia, 43600 UKM, Bangi Selangor, MALAYSIA

*Corresponding author: razaq@ukm.edu.my

\begin{abstract}
To cite this article: Abdul Aziz Rahman, Abdul Razaq Ahmad, Jalaluddin Abdul Malek and Mohd Mahzan Awang. 2016. Penglibatan sosial dan pembudayaan nilai murni melalui pembelajaran tidak formal dalam kalangan penduduk bandar Putrajaya. Kajian Malaysia 34(2): 75-100. http://dx.doi.org/10.21315/km2016.34.2.4
\end{abstract}

To link to this article: http://dx.doi.org/10.21315/km2016.34.2.4

\begin{abstract}
ABSTRAK
Kajian ini bertujuan untuk mengkaji penglibatan sosial, pembudayaan nilai melalui pembelajaran tidak formal dan amalan nilai murni dalam kalangan penduduk di bandar raya pintar Putrajaya, Malaysia. Seramai 414 orang penduduk bandar raya pintar Putrajaya telah mengambil bahagian dalam kajian ini. Pengumpulan data dilakukan dengan menggunakan soal selidik berdasarkan Teori Pembelajaran Tidak Formal Orang Dewasa dan adaptasi soal selidik yang berkaitan dengan nilai komuniti bandar. Bagi menentukan kesahan dan kebolehpercayaan soal selidik, kajian rintis telah dilakukan. Kajian rintis ini melibatkan 30 orang penduduk bandar raya pintar Putrajaya dan hasil nilai alfa Cronbach menunjukkan setiap item yang digunakan bagi mengukur konstruk yang dikaji mempunyai nilai kebolehpercayaan yang tinggi. Analisis data telah dilakukan dengan menggunakan statistik deskriptif dan inferensi. Dapatan kajian menunjukkan bahawa penglibatan sosial dalam kalangan penduduk bandar raya pintar Putrajaya berada pada tahap rendah serta pembudayaan nilai melalui pembelajaran tidak formal dan amalan nilai murni berada pada tahap sederhana. Analisis inferensi menunjukkan terdapat perbezaan yang signifikan bagi penglibatan sosial penduduk bandar raya pintar Putrajaya berdasarkan jantina. Selain itu, tidak terdapat perbezaan yang signifikan berdasarkan jantina
\end{abstract}


terhadap pembudayaan nilai melalui pembelajaran tidak formal dan amalan nilai murni. Namun, hasil kajian menunjukkan bahawa terdapat perbezaan yang signifikan terhadap penglibatan sosial, pembudayaan nilai melalui pembelajaran tidak formal dan amalan nilai murni berdasarkan taraf pendidikan. Kajian ini juga mendapati bahawa terdapat sumbangan yang signifikan antara penglibatan sosial dan pembudayaan nilai melalui pembelajaran tidak formal terhadap amalan nilai murni dalam kalangan penduduk bandar raya pintar di Putrajaya. Implikasi kajian ini mendapati bahawa pihak berkuasa perlu meningkatkan usaha, program dan aktiviti dalam meningkatkan nilai dalam komuniti bandar.

Kata kunci dan frasa: penglibatan sosial, pembelajaran tidak formal, amalan nilai murni, pembandaran, kejiranan

\begin{abstract}
This study aims to investigate the social participation, values culturalisation through the means of informal learning and values practices among residents of Putrajaya Smart City. A total of 414 residents participated in this study. Data collection was conducted by using a questionnaire based on Theory of Adults' Informal Learning and questionnaires related to rural community values. A pilot study which involved 30 residents of Putrajaya was conducted to test the validation and reliability of the questionnaire. The results from the Cronbach alpha revealed that all items that were used to measure the constructs have high reliability value. Descriptive and inferential statistics were used to analyse the data. Results showed that the social participation among the residents is at low level and the values culturalisation via informal learning and values practices is at moderate level. Inferential analysis illustrated that there is a significant difference for social participation according to gender. However, there is no significant difference between genders for the values culturalisation through informal learning and values practices. In regard to education level, there is a significant difference on social participation, values culturalisation through informal learning and values practices. This study also found that there is a significant contribution between social participation and values culturalisation through informal learning on values practices among the residents of Putrajaya. The implication of this study suggests that various efforts, programmes and activities has to be implemented to enhance values among the urban community. Based on these findings, this study suggests that the local authorities should take further actions and initiatives to enhance urban community values.
\end{abstract}

Keywords and phrases: social participation, informal learning, values culturalisation, neighbourhood 


\section{LATAR BELAKANG}

Dalam konteks sejarah pembandaran di Malaysia, model pembangunan bandar terancang adalah bertujuan untuk memenuhi keperluan perdagangan dan kegiatan ekonomi di Tanah Melayu yang bermula dengan kemunculan entiti pentadbiran Negeri-negeri Selat, bandar perdagangan George Town, Singapura dan Melaka yang lengkap dengan jaringan pengangkutan, susunan bangunan yang teratur disertai dengan kemudahan pusat kegiatan komuniti dan institusi pendidikan (Shaharudin et al., 2013). Kegiatan pembandaran merupakan elemen penting dalam sejarah pembangunan tamadun manusia serta merupakan ciri penting yang berkembang daripada kemunculan petempatan kekal kepada kehidupan bertamadun. Kehidupan di bandar merupakan kayu ukur tamadun kerana melambangkan kemajuan dan perkembangan pemikiran masyarakat (Nik Hassan dan Zuliskandar, 2011). Di bawah Rancangan Pembangunan Ekonomi yang digariskan dalam Pelan Rancangan Malaysia, kegiatan perdagangan dan pembangunan industri membawa kepada kemunculan bandar-bandar baru.

Perkembangan kehidupan masyarakat telah mengalami transformasi daripada kehidupan tradisional kepada kehidupan moden yang berteraskan teknologi perindustrian dan kini berteraskan teknologi maklumat dan komunikasi (TMK). Perubahan ini memerlukan konsep pemikiran baru dalam kalangan masyarakat tentang kehidupan bandar moden yang dilengkapi dengan kemudahan TMK dan pembudayaan nilai-nilai murni yang berbeza daripada kehidupan di bandar sebelum ini yang lebih bersifat individualistik dan materialistik. Dalam erti kata lain, penduduk bandar perlu mempunyai keupayaan dalam menerima konsep kehidupan bandar raya pintar yang diketengahkan (Masuda, 1990; Sardar, 1988). Bandar menjadi tempat himpunan pelbagai lapisan pendidikan dan sumber ilmu pengetahuan, menyediakan pelbagai lapisan pekerjaan dan perumahan, menjadi wadah untuk berinteraksi antara penduduk dalam bandar itu sendiri dan penduduk luaran sehingga ke peringkat global. Sekaligus menjadi lambang bagi jati diri dan kekuatan negara.

Legatum Prosperity Index menyenaraikan kesejahteraan hidup rakyat Malaysia di tangga ke-44 daripada 142 negara pada tahun 2013 (Asyraf et al., 2014). Lapan elemen dalam penilaian kesejahteraan rakyat yang digunakan merangkumi modal sosial, kebebasan individu, keselamatan, kesihatan, pendidikan, tadbir urus, keusahawanan dan ekonomi. Walaupun data Legatum Prosperity Index menunjukkan bahawa ekonomi Malaysia bertambah baik iaitu berada pada tangga ke-8 pada tahun 2013 berbanding tangga ke-17 pada tahun 2011; aspek kesejahteraan dari segi keselamatan semakin membimbangkan apabila kedudukan negara telah menjunam daripada tahun 2011 (tangga ke-53) ke-64 pada tahun 2013. Berdasarkan aspek kualiti hidup berkaitan dengan kualiti pendidikan, Malaysia berada di tangga ke-34 pada tahun 2013 berbanding tangga ke-35 pada tahun 2011. Kedudukan dalam Asia Pasifik menunjukkan bahawa Malaysia berada di tangga ke-8 mengatasi Thailand (tangga ke-11), Filipina 
(tangga ke-16) dan Indonesia (tangga ke-17). Secara keseluruhannya, analisis data daripada kajian ini menunjukkan bahawa kualiti hidup masyarakat adalah penting dan perlu diberi perhatian lanjut (Asyraf et al., 2014). Kajian terhadap kesejahteraan hidup di bandar menunjukkan banyak isu dan masalah yang menjejaskan kualiti hidup masyarakat bandar maka kajian empirikal yang lebih lanjut adalah diperlukan (Samsuhaizad, Jamaluddin dan Azahan, 2014).

\section{TUJUAN KAJIAN}

Kajian ini bertujuan untuk menilai pelaksanaan praktikal Pelan Tindakan Pembudayaan Nilai-nilai Murni dalam kalangan penduduk bandar raya pintar Putrajaya bagi memenuhi spesifikasi kebolehhunian bandar yang mesra penduduk dan sejahtera. Kajian dijalankan bagi mengkaji penglibatan penduduk dalam aktiviti sosial, pembudayaan nilai-nilai murni melalui pembelajaran tidak formal dan amalan nilai-nilai murni.

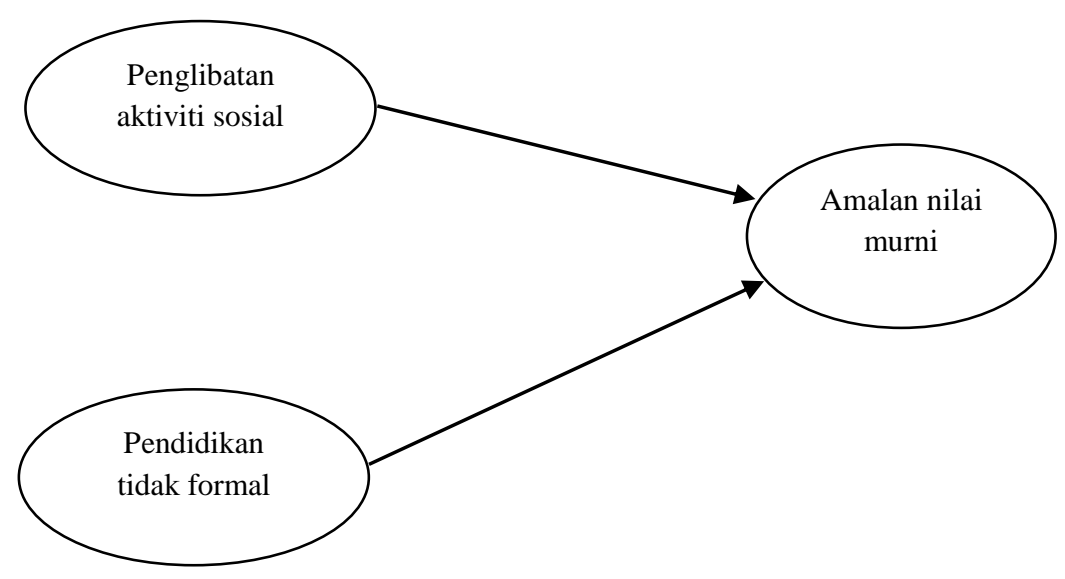

Rajah 1: Kerangka konseptual kajian.

Secara spesifiknya, kajian ini bertujuan untuk:

1. Menentukan tahap penglibatan sosial, pembudayaan nilai murni melalui pembelajaran tidak formal dan amalan nilai murni dalam kalangan penduduk bandar raya pintar Putrajaya, Malaysia;

2. Mengenal pasti perbezaan penglibatan sosial, pembudayaan nilai murni melalui pembelajaran tidak formal dan amalan nilai murni berdasarkan jantina dan taraf pendidikan; dan

3. Mengenal pasti hubungan antara penglibatan aktiviti sosial dan pembudayaan nilai murni dengan pembelajaran tidak formal dengan amalan nilai murni. 


\section{PROSES PERBANDARAN DAN KUALITI HIDUP}

Kejayaan sesebuah negara kini tidak lagi diukur mengikut dimensi ekonomi dan pembangunan fizikal semata-mata, malah turut didukung oleh pembangunan modal insan yang berkualiti. Justeru, dalam hal ini kualiti kehidupan di bandar dijadikan sebagai penanda aras kemodenan tersebut. Dalam menilai kualiti hidup di Malaysia, kajian terhadap pendatang luar ke Malaysia telah dilakukan oleh Expat Insider (2015) yang mendapati bahawa kualiti hidup di Malaysia secara keseluruhan diletakkan pada tangga ke-37. Empat aspek yang dinilai dalam penentuan ranking tersebut adalah berkaitan dengan pengisian waktu senggang, kegembiraan peribadi, pengangkutan dan kesihatan serta keselamatan dan kesejahteraan diri. Ulasan terhadap kajian tersebut menunjukkan bahawa wujud pertalian langsung di antara pembudayaan nilai murni dengan kualiti hidup masyarakat bandar. Biarpun wujud perdebatan konsep kualiti hidup (Samsuhaizad, Jamaluddin dan Azahan, 2014) susulan daripada perbezaan dimensi dalam pengukuran kualiti hidup, kebanyakan hujah yang diberikan adalah berkisar kepada ruang lingkup kesejahteraan hidup (Grant et al., 1990; Ferrans 1990; Samsuhaizad, Jamaluddin dan Azahan, 2014). Kajian lampau terhadap hubung kait di antara dua aspek ini (iaitu amalan kehidupan dan kualiti hidup) menunjukkan secara jelas bahawa pendidikan sebagai faktor utama kepada kualiti hidup. Kajian Mohd. Mahzan et al. (2013) mendapati bahawa kualiti hidup masyarakat mempunyai kaitan langsung dengan proses pendidikan secara formal dan tidak formal. Penekanan kepada aspek tingkah laku positif akan menyuburkan lagi nilai dana amalan nilai murni dalam kalangan masyarakat.

Falsafah kebendaan dalam pembangunan bandar hendaklah diimbangi dengan aspek kemanusiaan terutamanya pembudayaan nilai-nilai kepada seluruh warga bandar, agar nilai kemanusiaan dan jati diri masyarakat tidak tertutup oleh simbol materialistik dengan mengembalikan semangat bandar dalam satu lingkungan yang terpelihara dan sejahtera. Bermula pada tahun 2001, konsep pembudayaan nilai telah dilancarkan bagi bandar raya pintar Putrajaya dengan berteraskan kepada konsep hubungan antara manusia dengan tuhan, hubungan dengan manusia lain dan hubungan dengan alam sekitar. Sabari (2006) dalam kajiannya menyatakan bahawa pembangunan dan kemajuan sesebuah bandar adalah bergantung kepada keharmonian dan kesepaduan penduduk masyarakat setempat. Masyarakat yang mengamalkan nilai-nilai murni dalam kehidupan seharian adalah masyarakat yang bertamadun. Kajian oleh Asmah (2005) menyatakan bahawa komuniti yang wujud di sesebuah negara merupakan unsur yang terpenting dalam melahirkan suasana aman dalam negara berkenaan. Kehidupan sesebuah komuniti yang baik berkait rapat dengan kesihatan keluarga dan individu yang mendiami sesebuah negara. Dewasa ini, kebanyakan daripada masyarakat sudah dapat melihat kepesongan komuniti yang tidak lagi mengamalkan budaya dan nilai-nilai yang positif. Pelbagai kes yang tidak 
dijangkakan berlaku sewenang-wenangnya sehingga menjadi satu budaya keganasan yang melampau.

Menyedari hakikat ini, usaha-usaha yang menjurus kepada meningkatkan keupayaan modal insan menerusi penguasaan ilmu, pemupukan masyarakat berbudaya dan pemantapan aspek moral serta nilai-nilai murni yang tinggi perlu dipergiatkan. Justeru di sebalik pembangunan Putrajaya sebagai sebuah Pusat Pentadbiran Kerajaan Persekutuan yang terurus, tersisip agenda penting membina nilai, sikap serta mentaliti penghuninya dalam mengiringi pembangunan infrastruktur kelas pertama. Usaha ini penting ke arah menjadikan Putrajaya sebagai sebuah bandar contoh dan penanda aras bagi bandar-bandar lain di dalam dan luar negara, di samping menjadi mercu tanda kejayaan negara, baik dari aspek kecanggihan infrastruktur, jaringan telekomunikasi, pengangkutan dan perhubungan mahu pun kemurnian peribadi penduduknya yang memenuhi prinsip-prinsip tamadun dan kehidupan di bandar.

Dari segi idealnya apabila bandar raya pintar Putrajaya beroperasi, timbul persoalan bagaimana bentuk pengisian konsep bandar raya pintar melalui tadbir urus sivil dan penglibatan sivik dengan matlamat menjadikan Putrajaya bandar raya contoh kepada bandar yang mempunyai ciri keselamatan pada setiap masa. Hal ini termasuk dari aspek bersih dan sihat mental fizikal, memenuhi keperluan penduduk dengan penyediaan infrastruktur yang baik, mesra alam sekitar, bersemangat dan bertenaga bandar yang berbudaya murni serta bandar yang mempunyai pelbagai kemudahan bagi meningkatkan akses ilmu (Unit Pemodenan Tadbiran dan Perancangan Pengurusan Malaysia [MAMPU], 2011). Untuk merealisasikan iltizam tersebut, MAMPU (2011) bersama Perbadanan Putrajaya (PPj) telah membangunkan Pelan Tindakan Pembudayaan Amalan Nilai-nilai Murni Putrajaya sebagai wadah untuk memacu Putrajaya sebagai "Bandar dengan komuniti berbudaya nilai-nilai murni dan tahap sosial yang baik". Model masyarakat yang dikehendaki ialah berbudi bahasa, berbudaya ziarah-menziarahi, bergotong-royong, peramah, bebas jenayah, serta masjid dan surau dijadikan sebagai pusat kegiatan masyarakat dan berperanan aktif dalam komuniti.

Proses pembandaran di Malaysia melibatkan pelbagai aktiviti ekonomi, pergerakan barangan dan manusia. Pembangunan dan pertumbuhan bandar yang tidak terkawal serta sistem bandar yang tidak tersusun di peringkat awal pembentukannya menyebabkan pelbagai isu wujud di bandar-bandar utama seperti Kuala Lumpur, George Town, Johor Bahru dan Alor Setar. Peningkatan pembangunan turut menjadikan keluasan kawasan bandar bertambah sempit dan persekitaran yang ideal untuk kehidupan penduduk semakin terhad (Soja, 2000). Percampuran yang berlaku dengan kepelbagaian nilai budaya akibat penggunaan tenaga kerja asing menjadikan usaha pembentukan identiti dan pembudayaan nilai-nilai murni juga menghadapi cabaran besar yang perlu diatasi. Malahan, pembudayaan juga sukar dilaksanakan kerana tidak berakar umbi dari generasi ke 
generasi disebabkan oleh penduduknya yang hanya tinggal sementara dan tidak kekal.

Masalah lain yang timbul ialah penerusan status dan kelas sosial mengikut status pekerjaan dalam kehidupan di luar pejabat yang dapat dilihat secara jelas melalui kawasan petempatan (apartment, rumah teres dan banglo), kelompok kejiranan dan aktiviti kemasyarakatan sehingga mewujudkan pemisahan dan segregasi sosial yang ketara, sehingga tidak wujud percampuran antara kumpulan status sosial pekerja dengan kumpulan pegawai pertengahan dan atasan. Keadaan ini jelas mewujudkan jurang yang ketara dan kecemburuan sosial dalam kalangan penduduk hingga menyebabkan langkah pembudayaan amalan nilai-nilai murni menghadapi masalah disebabkan penglibatan golongan kelas menengah dan atasan adalah terhad berbanding penglibatan golongan kelas pekerja.

Pembangunan bandar sedia ada menghadapi pelbagai masalah fizikal dan sosial ekoran daripada pembangunan yang tidak terkawal atau ketidakseimbangan pembangunan. Isu-isu seperti petempatan-petempatan segera, kesesakan lalu lintas, banjir kilat, tanah runtuh, pencemaran udara dan air, jenayah, dan sebagainya merupakan permasalahan semasa di kawasan bandar. Hal ini ditambah pula dengan ketiadaan arah tuju pembangunan sesebuah bandar akibat daripada penglibatan pelbagai pihak dengan agenda-agendanya yang tersendiri (Santiago, Galster dan Pettit, 2003). Kadar jenayah, vandalisme dan salah laku di bandar raya Putrajaya, menunjukkan sering berlaku sehingga mendesak kerajaan untuk melakukan inisiatif pemutihan kawasan black spot (Kementerian Kesejahteraan Bandar, Perumahan dan Kerajaan Tempatan, 2014). Bagi menjadikan bandar raya pintar Putrajaya sebagai kawasan yang selamat dan kondusif, pendidikan dan kesedaran tentang keprihatinan penduduk kawasan kejiranan Putrajaya terhadap usaha membanteras segala bentuk jenayah dan salah laku merupakan satu usaha yang perlu diberi keutamaan kerana lebih bersifat menyeluruh dan merupakan pemangkin kepada kesejahteraan hidup bandar raya Putrajaya.

\section{PEMBUDAYAAN NILAI MURNI}

Nilai murni adalah bersifat universal yakni terdapat ciri-ciri sepunya yang dikongsi secara global. Dalam konteks global, amalan nilai murni dikaitkan secara langsung dengan kesejahteraan dan kesihatan diri. Pertubuhan Kesihatan Sedunia (World Health Organisation [WHO], 1948) mendefinisikan kesihatan sebagai suatu keadaan fizikal, minda dan sosial yang sihat, cergas, cerdas serta bebas dari sebarang penyakit. Johnson, Scholes dan Sexty (1989) pula merujuk kesihatan keluarga dengan keadaan institusi keluarga yang tidak berperaturan, tiada pendirian dan tidak teguh (deinstituitionalisation). Kesannya membawa kepada sebuah keluarga yang tidak berfungsi dan penyebab kepada kesakitan 
mental. Banyak faktor yang mempengaruhi keadaan ini berlaku dalam sesebuah keluarga seperti komunikasi, faktor biologi, kurang sokongan, dan elemen emosi (Johnson, 2000). Kewujudan faktor-faktor ini menyebabkan ahli-ahli keluarga yang tidak berpenyakit akan mula merasai penyakit sama ada secara dalaman atau luaran. Elemen-elemen seperti sokongan, kasih sayang, dan perhatian oleh keluarga merupakan elemen penting ke arah kesejahteraan individu dalam keluarga. Motivasi secara intrinsik ke atas ahli-ahli dalam keluarga mewujudkan satu keadaan tenang, tenteram dan harmoni dalam diri. Keluarga yang sihat dan komuniti yang sejahtera mencerminkan individu dan bangsa yang ada di sesebuah negara itu sebagai kelompok komuniti yang sejahtera, makmur, dan harmoni dalam segenap aspek seperti politik, ekonomi dan sosial. Prioriti terhadap amalan nilai murni mempunyai kaitan rapat dengan pelbagai faktor persekitaran budaya termasuklah ideologi, nilai keagamaan, budaya dan norma bagi setiap masyarakat. Dalam konteks pembudayaan nilai murni dari perspektif Islam menerusi konsep masyarakat madani pula, amalan nilai murni adalah gagasan yang menggambarkan masyarakat beradab yang memacu pada nilai-nilai kebajikan dengan mengembangkan dan menerapkan prinsip-prinsip interaksi sosial yang kondusif bagi penciptaan cabaran demokratis dalam kehidupan bermasyarakat dan bernegara. Masyarakat madani adalah masyarakat yang beradab, menjunjung tinggi nilai-nilai kemanusiaan, yang maju dalam penguasaan ilmu pengetahuan, dan teknologi. Masyarakat madani juga adalah sebuah masyarakat demokratis di mana para anggotanya menyedari akan hak-hak dan kewajipannya dalam menyuarakan pendapat dan mewujudkan kepentingankepentingannya; di mana pemerintahannya memberikan peluang yang seluasluasnya bagi kreativiti warga negara untuk mewujudkan program-program pembangunan di wilayahnya. Pemodenan negara telah menyaksikan banyak nilai murni digabung jalin dalam dokumen rasmi yang dikodkan sebagai undangundang dan peraturan.

Pembudayaan ialah satu proses pemberian nilai-nilai budaya dan agama kepada seseorang, sehingga yang bersangkutan mempunyai perilaku yang sopan, berbudaya, bermoral dan beretika (Prayinto, 1987). Proses pembudayaan dan pengetahuan berlangsung dalam keluarga dan persekitaran yang berkaitan. Sementara proses pendidikan bermula sejak zaman kanak-kanak. Pengumpulan budaya, ilmu dan kemahiran yang harus dikuasai dan diwariskan dari generasi ke generasi meningkatkan kualiti dan jumlahnya. Proses pembudayaan, pengetahuan dan pendidikan tidak hanya mencerminkan keadaan dan keperluan sekitar lapangan pekerjaan saja, namun harus juga berorientasikan keperluan kehidupan individu dalam masyarakat. Nilai murni dalam masyarakat perlu diamalkan oleh setiap individu bagi mewujudkan suasana yang harmoni (Zakaria, Noranizah dan Abdul Fatah, 2012; Mior Khairul Azrin, 2011). Antara ciri-ciri nilai murni tersebut ialah baik hati, berdikari, hormat-menghormati, kasih sayang, keadilan, kebebasan, kerjasama dan semangat kemasyarakatan. 
Nilai murni merupakan satu perlakuan yang baik di antara hubungan sesama manusia yang merangkumi aspek agama, sosial, kejiranan dengan tujuan membentuk sebuah masyarakat yang bersatu padu (Abdul Samad, 2010). Nilai murni juga merujuk kepada nilai positif yang diamalkan dalam satu budaya yang menekankan ke arah kesopanan sama ada dari segi percakapan, perbuatan dan merupakan pelengkap kepada masyarakat (Wan Rozali, 2008). Nilai murni boleh memartabatkan masyarakat untuk menjadi masyarakat kelas pertama yang berteraskan prinsip yang mulia sama ada dalam agama, komuniti bangsa dan negara. Masyarakat yang mengamalkan nilai-nilai murni dalam kehidupan harian mereka adalah masyarakat yang bertamadun (Sabari, 2006). Sekiranya seseorang individu itu diterapkan dengan nilai murni seperti hormat menghormati, jujur dan amanah, secara tidak langsung akhlak yang mulia dapat dibentuk (Khairani, 2012).

Berlandaskan keadaan di atas, maka kerajaan berhasrat menjadikan bandar raya Putrajaya sebagai tempat idaman dan bandar raya contoh dalam membangunkan sebuah bandar madani yang mempunyai penghuni berakhlak mulia, berbudi pekerti dan mengamalkan nilai-nilai murni. Usaha kerajaan untuk menerapkan nilai-nilai murni di dalam hati masyarakat telah mula berkembang dan amat giat dilakukan menerusi pelbagai pendekatan termasuklah pengenalan kurikulum baru yang berasaskan penilaian berterusan, penilaian berasaskan sekolah, dan kurikulum bersepadu (Tajul Arifin, 2010). Usaha melalui iklan, kempen, dan dasar kerajaan telah memberi nafas baru kepada masyarakat untuk menjadi masyarakat bertamadun serta mempunyai nilai yang tinggi yang mampu menjadikan sesebuah kawasan tersebut menjadi lebih baik untuk didiami. Pembudayaan amalan nilai-nilai murni yang hendak dimodelkan dalam konsep pembangunan bandar raya pintar Putrajaya memerlukan pendekatan yang holistik bagi mewujudkan masyarakat yang mempunyai jati diri dan berintegriti.

\section{Aktiviti Tidak Formal}

Simmons (1980) mendefinisikan pembelajaran tidak formal sebagai aktivitiaktiviti yang berlaku di luar sekolah seperti kursus berkaitan celik huruf dan pembangunan orang dewasa. Jalaluddin, Abdul Razaq dan Mohd Mahzan (2014) pula mengaitkan pembelajaran tidak formal dengan pembelajaran sepanjang hayat. Manakala, Meriam, Baumgarther dan Caffarella (2007) memperincikan pembelajaran tidak formal sebagai proses pembelajaran orang dewasa untuk memperbaiki status diri dan menjalankan peranannya untuk perubahan sikap, nilai dan kemahiran. Knowles (1980) pula melihat pembelajaran tidak formal sebagai satu set aktiviti yang tersusun dan dijalankan oleh pelbagai institusi untuk mencapai objektif tertentu dalam pendidikan. Menurut Knowles (1980) lagi, pembelajaran tidak formal memerlukan penelitian mendalam kerana orang dewasa mempunyai ciri pembelajaran yang tersendiri dan berbeza dengan pembelajaran kanak-kanak (dikenali sebagai pedagogi). Orang dewasa 
mempunyai pengalaman yang lebih mendalam berbanding kanak-kanak. Orang dewasa juga mempunyai konsep diri serta mempunyai orientasi pembelajaran objektif kendiri dalam pembelajaran. Justeru dalam konteks pembudayaan nilai murni di bandar, fokus kepada memahami bagaimana orang dewasa membudayakan amalan nilai murni menerusi pembelajaran tidak formal amat penting. Hal ini kerana penduduk bandar yang terdiri daripada orang dewasa mempunyai pendedahan yang berbeza-beza sama ada pendedahan berbentuk pengalaman serta pendedahan kepada media baru dan rakan berlainan latar budaya. Oleh itu, pelbagai aktiviti yang berupaya memupuk nilai murni menerusi pembelajaran tidak formal perlu dirancang dan dilaksanakan secara bersepadu. Dalam kajian ini, aktiviti pembelajaran tidak formal yang diteliti adalah merangkumi aktiviti penghayatan kerohanian dan pendidikan moral komuniti; pengukuhan semangat kejiranan menerusi pelbagai usaha yang menemukan ahli komuniti dalam majlis; pemantapan institusi kekeluargaan menerusi ceramah dan konsultansi; aktiviti yang memupuk amalan menghormati undang-undang dan peraturan; program kerjasama dengan pelbagai agensi pelaksana; dan kerjasama dengan agensi kerajaan dan Badan Bukan Kerajaan (Non-governmental organisation, NGO). Selain itu, perlu dijelaskan bahawa aktiviti yang dirancang untuk pemupukan nilai murni penduduk bandar harus mengambil kira pelbagai faktor dan amat bergantung kepada autoriti pelaksana serta latar budaya sosial para penghuni kota. Dalam konteks kajian ini, badan berautoriti adalah Perbadanan Putrajaya. Pembelajaran tidak formal memainkan peranan sebagai "acknowledging the importance of education, learning and training which take place outside recognised educational institution" (United Nation Educational Scientific Organisation, 2015: 1). Shamsudin (1993) menganggap terdapat empat peranan asas yang dimainkan oleh pembelajaran tidak formal, iaitu (1) menyediakan pendidikan yang relevan dengan keperluan masyarakat, (2) mencapai objektif khusus kepada kumpulan sasaran tertentu, (3) menyelenggara program yang dapat menyemarakkan nilai dan budaya, dan (4) menggunakan kaedah pembelajaran yang fleksibel. Pembudayaan nilai murni melalui aktiviti tidak formal merujuk kepada aktiviti pembelajaran tidak formal di surau dan pusat komuniti, aktiviti-aktiviti sosial dan tingkah laku tidak formal sama ada dalam keluarga atau masyarakat yang menjurus kepada nilai-nilai murni.

\section{PENGLIBATAN SOSIAL DAN KUALITI HIDUP}

Kajian lampau menunjukkan hubungan yang jelas di antara kualiti hidup dan penglibatan sosial dalam aktiviti sihat. Sebagai contoh, kajian yang dijalankan oleh Muzafar Shah dan Baharom (2009) merumuskan bahawa wujud hubungan langsung antara kegiatan dan aktiviti sihat dengan kesejahteraan individu dan kualiti kehidupan. Kualiti hidup juga melambangkan kemajuan sesebuah negara. 
Rakyat jelata di bawah sesebuah pemerintahan berhak memiliki dan memperoleh kualiti hidup yang diperlukan (Norhaslina, 2006). Pengukuran tentang kualiti hidup telah dibangunkan secara sistematik oleh United Nations Development Programme (UNDP) menerusi Indeks Pembangunan Insan (Human Development Index). Indeks Pembangunan Insan diukur berdasarkan tiga dimensi asas iaitu jangka hayat dan kehidupan sihat, akses kepada ilmu pengetahuan, serta piawaian kehidupan. Berdasarkan dimensi ini, nilai Indeks Pembangunan Insan di Malaysia pada tahun 2014 adalah 0.779 yang dikategorikan sebagai negara yang mempunyai pembangunan yang tinggi (United Nations Development Programme, 2015). Kefahaman terhadap konsep dan pengertian kualiti hidup sosial juga berbeza berdasarkan indeks tertentu di sesebuah negara. Namun, walaupun ia mempunyai pelbagai tafsiran dan pengertian yang berbeza, tetapi secara asasnya kualiti hidup sosial mengikut konteks perbincangan ini merupakan keperluan asas pada tahap minimum yang sepatutnya dimiliki dan dinikmati oleh penghuni sesebuah bandar. Syarat utama dalam melahirkan komuniti budaya murni dan tahap sosial yang baik bergantung pada amalan seharian penduduk termasuk penglibatan mereka dalam semua program pembangunan komuniti dan program di bawah Pelan Tindakan Pembudayaan Nilai-nilai Murni di Putrajaya.

Faktor yang dilihat menjadi pemangkin kepada kempen kesedaran nilai murni melalui pelbagai cara termasuklah program pemupukan nilai murni, forum dan ceramah serta aktiviti keagamaan yang dapat membantu meningkatkan amalan nilai murni dalam kalangan penduduk kawasan kejiranan. Komponen amalan nilai-nilai murni merupakan satu penilaian terhadap amalan nilai-nilai murni yang dibincangkan sebelumnya telah diamalkan dengan baik oleh penduduk-penduduk kawasan kejiranan dari perspektif mereka sendiri (Norhaslina, 2006). Penglibatan penduduk yang dikaji ialah tolong-menolong seperti membantu orang lain dalam kesusahan dan kemalangan, memenuhi jemputan ke majlis kenduri, tahlil dan sebagainya, memelihara hubungan baik dengan jiran-jiran dan terlibat dalam aktiviti sosial yang dianjurkan di kawasan kejiranan (Sabari, 2006).

\section{REKA BENTUK KAJIAN}

Kajian tinjuan ini melibatkan seramai 414 orang penduduk di bandar raya pintar Putrajaya. Merujuk jadual persampelan Krejcie dan Morgan (1970), sebanyak 414 sampel adalah memadai bagi populasi penduduk Putrajaya yang berjumlah sekitar 87,100 (Jabatan Statistik Malaysia, 2016). Kajian ini menggunakan soal selidik untuk mengukur penglibatan penduduk dalam aktiviti sosial menerusi pembelajaran tidak formal serta hubungannya dengan amalan nilai murni. Soal selidik telah diadaptasi berdasarkan Teori Pembelajaran Tidak Formal Orang Dewasa oleh Meriam, Baumgarther dan Caffarella (2007) serta adaptasi daripada soal selidik oleh penyelidik lampau (Haryati, 2007; Wan Rozali, 2008; Katiman 
et al., 2010) dan model Pelan Tindakan Pembudayaan Nilai-nilai Murni (Unit Pemodenan Tadbiran dan Perancangan Pengurusan Malaysia, 2011). Soal selidik yang digunakan mengandungi empat bahagian utama iaitu bahagian maklumat demografi responden (10 item); bahagian penglibatan penduduk dalam aktiviti sosial (10 item); bahagian nilai-nilai murni melalui pembelajaran tidak formal (10 item); dan amalan nilai-nilai murni (10 item). Bahagian nilai-nilai murni telah diuji dan diguna pakai oleh Unit Pemodenan Tadbiran dan Perancangan Pengurusan Malaysia (Abdul Aziz, 2012). Soal selidik yang digunakan dalam kajian ini telah diuji kesahan dan kebolehpercayaan menerusi ujian kesahan kandungan, kesahan muka dan analisis kebolehpercayaan. Analisis kebolehpercayaan dilakukan menerusi kajian rintis terhadap 30 responden di Putrajaya. Nilai alfa Cronbach daripada analisis kebolehpercayaan menunjukkan kesemua item dalam konstruk yang dikaji berada pada tahap tinggi dengan purata 0.95. Mohd. Majid (2000) menyarankan nilai alfa Cronbach pada aras $0.70 \mathrm{ke}$ atas, sebagai nilai Alpha yang mempunyai kebolehpercayaan yang tinggi. Persampelan kajian dilakukan secara rawak mudah kerana populasi yang dikaji telah dikenal pasti terlebih awal (Gay dan Airasian, 2000) iaitu penduduk di bandar raya Putrajaya.

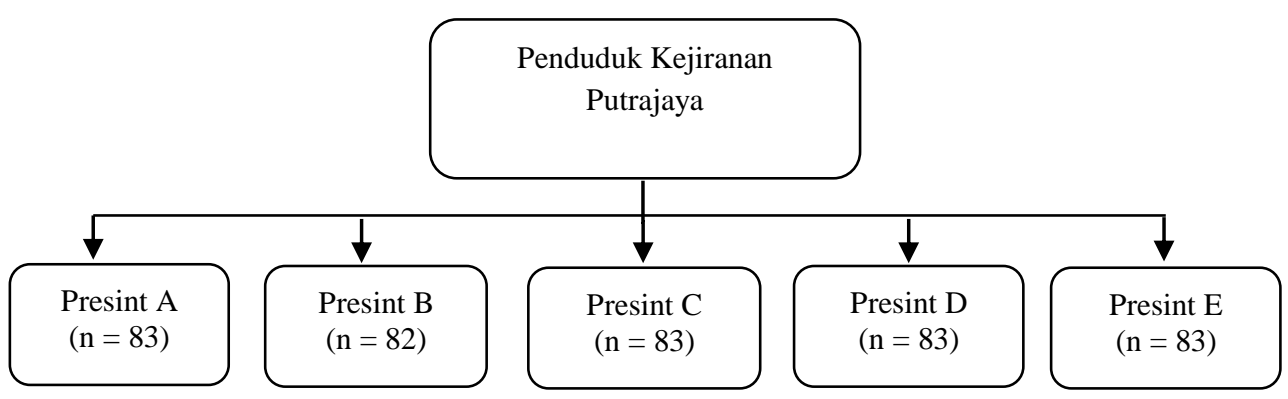

Rajah 2 : Pemilihan sampel kajian.

Rajah 2 menunjukkan bilangan sampel bagi setiap presint yang terlibat dalam kajian ini dipilih secara rawak mudah bagi mendapatkan bilangan sampel yang dapat mewakili populasi seperti yang telah dinyatakan dalam Jadual Krejcie dan Morgan (1970). Penyelidikan ini dilakukan dengan mematuhi etika penyelidikan. Justeru lokasi sebenar presint kajian adalah dirahsiakan kerana ia berupaya memberi pendedahkan kepada kerahsiaan reponden.

\section{Analisis Data}

Analisis deskriptif yang melibatkan kekerapan, peratusan, min dan sisihan piawai digunakan bagi menentukan profil demografi kajian dan tahap penglibatan aktiviti sosial, pembudayaan nilai murni melalui pembelajaran tidak formal dan 
amalan nilai murni. Penentuan tahap penglibatan adalah berdasarkan skor min dan sisihan piawai. Tafsiran skor min dalam kajian ini adalah berdasarkan Jadual Interpretasi Skor Min yang menetapkan bahawa bagi Skala Likert 5-mata, skor min 1.00 hingga 2.33 dikategorikan sebagai tahap rendah; 2.34 hingga 3.66 adalah tahap sederhana; manakala skor min 3.67 hingga 5.00 adalah tahap tinggi (Jamil, 2002). Analisis ujian $t$ bebas dan ANOVA satu hala digunakan untuk mengenal pasti perbezaan penglibatan aktiviti sosial, pembudayaan nilai murni melalui pembelajaran tidak formal dan amalan nilai murni berdasarkan jantina dan taraf pendidikan. Analisis korelasi Pearson pula digunakan untuk mengenal pasti hubungan antara penglibatan dalam aktiviti sosial dan amalan nilai murni melalui pembelajaran tidak formal dengan amalan nilai murni. Pemboleh ubah bebas adalah penglibatan aktiviti sosial, pembudayaan nilai murni melalui pembelajaran tidak formal dan amalan nilai murni; manakala pemboleh ubah bersandar adalah jantina dan taraf pendidikan.

\section{Demografi}

Kajian ini melibatkan 414 responden yang mendiami bandar raya pintar Putrajaya. Pecahan responden kajian adalah terdiri daripada 237 (57.2\%) lelaki dan 177 (42.8\%) wanita. Seramai 132 (31.9\%) responden memiliki kelayakan akademik SPM/STPM/Sijil/setaraf; manakala 119 (28.7\%) responden berkelulusan Diploma. Sebanyak 163 (39.4\%) responden memilki Ijazah/Sarjana/PhD. Data kajian dianalisis dengan menggunakan perisian SPSS 22.0 .

\section{Analisis Tahap Penglibatan Sosial}

Analisis deskriptif telah dilakukan untuk menentukan tahap penglibatan sosial, nilai murni melalui pembelajaran tidak formal dan amalan nilai murni dalam kalangan penduduk bandar raya pintar Putrajaya, Malaysia.

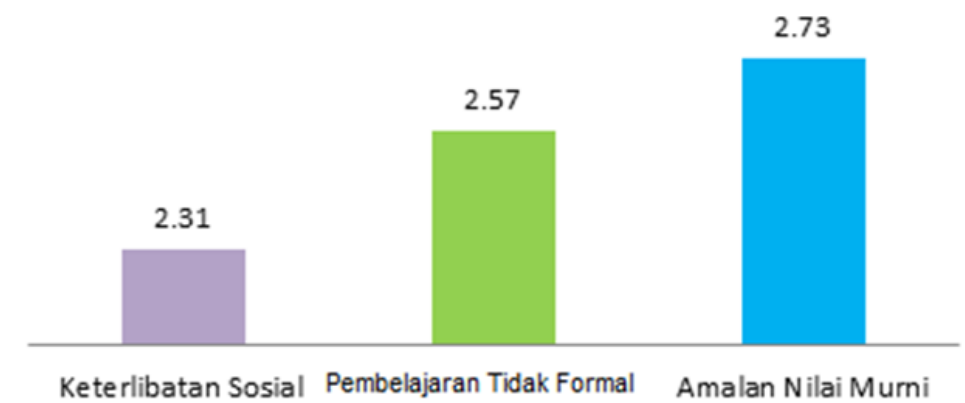

Rajah 3: Tahap penglibatan sosial, nilai murni melalui pembelajaran tidak formal dan amalan nilai murni penduduk bandar raya pintar Putrajaya. 
Dapatan kajian menunjukkan bahawa penglibatan sosial penduduk bandar raya pintar Putrajaya berada pada tahap yang rendah. Manakala bagi pembudayaan nilai murni melalui pembelajaran tidak formal dan amalan nilai murni berada pada tahap yang sederhana.

\section{Analisis Perbezaan Penglibatan Berdasarkan Jantina}

Analisis inferensi telah dilakukan untuk mengenal pasti perbezaan penglibatan sosial, nilai murni melalui pembelajaran tidak formal dan amalan nilai murni dalam kalangan penduduk bandar raya pintar Putrajaya, Malaysia berdasarkan jantina.

Jadual 1: Perbezaan penglibatan sosial, nilai murni melalui pembelajaran tidak formal dan amalan nilai murni dalam kalangan penduduk bandar raya pintar Putrajaya, Malaysia berdasarkan jantina

\begin{tabular}{lcccccc}
\hline Aspek & Jantina & $\mathrm{N}$ & Min & $\mathrm{T}$ & $\mathrm{df}$ & Sig. \\
\hline Penglibatan sosial & Lelaki & 237 & 2.17 & -4.926 & 412 & 0.000 \\
& Perempuan & 177 & 2.50 & & & \\
Pembelajaran tidak & Lelaki & 237 & 2.52 & -1.803 & 412 & 0.072 \\
formal & Perempuan & 177 & 2.64 & & & \\
Amalan niai murni & Lelaki & 237 & 2.38 & 0.532 & 412 & 0.595 \\
& Perempuan & 177 & 2.35 & & & \\
\hline
\end{tabular}

Hasil ujian- $t$ bebas menunjukkan terdapat perbezaan yang signifikan dalam penglibatan sosial penduduk bandar raya pintar Putrajaya berdasarkan jantina dengan nilai $t=-4.926 \mathrm{dan} \operatorname{sig}=0.000(p<0.05)$. Penduduk perempuan $(\min =2.50)$ menunjukkan penglibatan sosial yang lebih tinggi berbanding dengan penduduk lelaki $(\min =2.17)$. Manakala tiada perbezaan yang signifikan terhadap pembudayaan nilai murni melalui pembelajaran tidak formal dan amalan nilai murni dalam kalangan penduduk dari kedua-dua jantina.

\section{Analisis Perbezaan Penglibatan Berdasarkan Taraf Pendidikan}

Ujian ANOVA satu hala telah dikendalikan untuk meneliti perbezaan penglibatan sosial, nilai murni melalui pembelajaran tidak formal dan amalan nilai murni dalam kalangan penduduk bandar raya pintar Putrajaya berdasarkan taraf pendidikan. 
Jadual 2: Perbezaan penglibatan sosial, nilai murni melalui pembelajaran tidak formal dan amalan nilai murni dalam kalangan penduduk bandar raya pintar Putrajaya, Malaysia berdasarkan taraf pendidikan

\begin{tabular}{llccccc}
\hline Aspek & Taraf pendidikan & N & Min & $\begin{array}{l}\text { Sisihan } \\
\text { piawai }\end{array}$ & F & Sig. \\
\hline Penglibatan sosial & SPM/STPM/Sijil/setaraf & 132 & 2.10 & 0.581 & 12.001 & 0.000 \\
& Diploma & 119 & 2.31 & 0.674 & & \\
& Ijazah/Sarjana/PhD & 163 & 2.49 & 0.735 & & \\
Pembelajaran tidak & SPM/STPM/Sijil/setaraf & 132 & 2.28 & 0.625 & 19.975 & 0.000 \\
& Dormal & 119 & 2.60 & 0.699 & & \\
Amalan nilai murni & SPM/STPM/Sijil/setaraf & 132 & 2.17 & 0.534 & 12.951 & 0.000 \\
& Diploma & 119 & 2.36 & 0.657 & & \\
& Ijazah/Sarjana/PhD & 163 & 2.54 & 0.658 & & \\
\hline
\end{tabular}

Jadual 2 menunjukkan terdapat perbezaan yang signifikan terhadap penglibatan sosial $(\mathrm{F}=12.001$; Sig. $=0.000, p<0.05)$, nilai murni melalui pembelajaran tidak formal $(\mathrm{F}=19.975$; Sig. $=0.000, p<0.05)$ dan amalan nilai murni dalam kalangan penduduk $(\mathrm{F}=12.951$; Sig. $=0.000, p<0.05)$ berdasarkan taraf pendidikan. Analisis keseluruhan menunjukkan responden yang memiliki Ijazah/Sarjana/PhD mempunyai nilai min yang lebih tinggi berbanding taraf pendidikan Diploma dan SPM/STPM/Sijil/setaraf. Hal ini menunjukkan bahawa responden yang berpendidikan tinggi lebih giat terlibat dalam aktiviti sosial. Bagi melihat perbezaan tersebut dengan lebih terperinci, maka ditunjukkan dalam Jadual 3.

Jadual 3 menunjukkan terdapat perbezaan yang signifikan terhadap penglibatan sosial penduduk bandar raya pintar Putrajaya berdasarkan taraf pendidikan terutama bagi responden yang berkelulusan SPM/STPM/Sijil/setaraf dengan mereka yang memiliki Ijazah/Sarjana/PhD dengan catatan perbezaan min $=-0.385$ dan sig $=0.000(p<0.05)$. Hal ini bermakna bahawa responden yang memiliki kelayakan akademik tinggi (Ijazah/Sarjana/PhD) lebih kerap terlibat dalam aktiviti sosial berbanding dengan mereka yang berkelulusan SPM/STPM/Sijil/setaraf.

Dari segi pembudayaan amalan murni melalui pembelajaran tidak formal pula, hasil kajian menunjukkan bahawa terdapat perbezaan yang signifikan antara responden yang berkelulusan SPM/STPM/Sijil/setaraf dengan mereka yang memiliki Diploma. Catatan perbezaan min adalah $=-0.319$ dan sig $=0.001$ $(p<0.05)$. Hal ini bermakna responden yang berkelulusan Diploma lebih kerap terlibat dalam aktiviti sosial berbanding dengan responden yang berkelulusan SPM/STPM/Sijil/setaraf. Hasil kajian juga mendapati terdapat perbezaan yang signifikan dalam pembudayaan amalan murni melalui pembelajaran tidak formal 
antara taraf pendidikan SPM/STPM/Sijil/setaraf dengan taraf pendidikan Ijazah/Sarjana/PhD dengan catatan perbezaan $\min =-0.502$ dan Sig. $=0.000$ $(p<0.05)$. Responden berkelulusan Ijazah/Sarjana/PhD mempunyai penglibatan sosial yang lebih tinggi berbanding dengan penduduk dengan taraf pendidikan SPM/STPM/Sijil/setaraf.

Jadual 3: Post Hoc Scheffe perbezaan penglibatan sosial, nilai murni melalui pembelajaran tidak formal dan amalan nilai murni dalam kalangan penduduk bandar raya pintar Putrajaya, Malaysia berdasarkan taraf pendidikan

\begin{tabular}{|c|c|c|c|c|c|}
\hline Aspek & $\begin{array}{l}\text { (I) Taraf } \\
\text { pendidikan }\end{array}$ & (J) Taraf pendidikan & $\begin{array}{l}\text { Perbezaan } \\
\text { min (I-J) }\end{array}$ & $\begin{array}{l}\text { Ralat } \\
\text { piawai }\end{array}$ & Sig. \\
\hline \multirow{6}{*}{$\begin{array}{l}\text { Penglibatan } \\
\text { sosial }\end{array}$} & \multirow{2}{*}{$\begin{array}{l}\text { SPM/STPM/ } \\
\text { Sijil/setaraf }\end{array}$} & Diploma & -0.206 & 0.08488 & 0.054 \\
\hline & & Ijazah/Sarjana/PhD & $-0.385^{*}$ & 0.07863 & 0.000 \\
\hline & \multirow[t]{2}{*}{ Diploma } & SPM/STPM/Sijil/Setaraf & 0.206 & 0.08488 & 0.054 \\
\hline & & Ijazah/Sarjana/PhD & -0.179 & 0.08097 & 0.088 \\
\hline & \multirow{2}{*}{$\begin{array}{l}\text { Ijazah/Sarjana/ } \\
\mathrm{PhD}\end{array}$} & SPM/STPM/Sijil/setaraf & $0.385^{*}$ & 0.07863 & 0.000 \\
\hline & & Diploma & 0.179 & 0.08097 & 0.088 \\
\hline \multirow{6}{*}{$\begin{array}{l}\text { Pembelajaran } \\
\text { tidak formal }\end{array}$} & \multirow{2}{*}{$\begin{array}{l}\text { SPM/STPM/ } \\
\text { Sijil/Setaraf }\end{array}$} & Diploma & $-0.319^{*}$ & 0.086 & 0.001 \\
\hline & & Ijazah/Sarjana/PhD & $-0.502^{*}$ & 0.080 & 0.000 \\
\hline & \multirow[t]{2}{*}{ Diploma } & SPM/STPM/Sijil/setaraf & $0.319^{*}$ & 0.086 & 0.001 \\
\hline & & Ijazah/Sarjana/PhD & -0.183 & 0.082 & 0.084 \\
\hline & \multirow{2}{*}{$\begin{array}{l}\text { Ijazah/Sarjana/ } \\
\mathrm{PhD}\end{array}$} & SPM/STPM/Sijil/setaraf & $0.502^{*}$ & 0.080 & 0.000 \\
\hline & & Diploma & 0.183 & 0.082 & 0.084 \\
\hline \multirow{6}{*}{$\begin{array}{l}\text { Amalan nilai } \\
\text { murni }\end{array}$} & \multirow{2}{*}{$\begin{array}{l}\text { SPM/STPM/ } \\
\text { Sijil/setaraf }\end{array}$} & Diploma & -0.192 & 0.078 & 0.051 \\
\hline & & Ijazah/Sarjana/Ph.D & $-0.370^{*}$ & 0.073 & 0.000 \\
\hline & \multirow[t]{2}{*}{ Diploma } & SPM/STPM/Sijil/Setaraf & 0.192 & 0.078 & 0.051 \\
\hline & & Ijazah/Sarjana/Ph.D & -0.177 & 0.075 & 0.061 \\
\hline & \multirow{2}{*}{$\begin{array}{l}\text { Ijazah/Sarjana/ } \\
\text { PhD }\end{array}$} & SPM/STPM/Sijil/Setaraf & $0.370^{*}$ & 0.073 & 0.000 \\
\hline & & Diploma & 0.177 & 0.075 & 0.061 \\
\hline
\end{tabular}

Perbezaan yang signifikan dicatatkan pada amalan nilai murni penduduk bandar raya pintar Putrajaya berdasarkan taraf pendidikan. Responden berkelulusan SPM/STPM/Sijil/setaraf didapati berbeza dengan mereka yang berkelulusan Ijazah/Sarjana/PhD dengan catatan perbezaan $\min =-0.370$ dan Sig. $=0.000(p<0.05)$. Dapatan ini memberi makna bahawa responden yang memiliki Ijazah/Sarjana/PhD mempunyai amalan nilai murni yang lebih tinggi berbanding dengan responden yang berkelulusan SPM/STPM/Sijil/setaraf. 


\section{Analisis Sumbangan Penglibatan Sosial Terhadap Amalan Nilai Murni}

Analisis regresi berganda telah dijalankan bagi mengenal pasti sumbangan antara penglibatan penduduk dan pembudayaan nilai melalui pembelajaran tidak formal terhadap amalan nilai-nilai murni. Untuk membolehkan analisis regresi dijalankan dengan jayanya, analisis Casewise diagnostic telah dilakukan bagi menapis dan membuang data yang mengganggu kebolehpercayaan dapatan regresi. Selain itu, beberapa andaian regresi linear seperti ujian kesamaan varians dan ujian normaliti serta aspek-aspek koloneariti turut dijalankan mengikut kaedah yang ditentukan (Hair et al., 1998).

Jadual 4: Regresi berganda sumbangan penglibatan sosial dan nilai murni melalui pembelajaran tidak formal terhadap amalan nilai murni dalam kalangan penduduk bandar raya pintar Putrajaya, Malaysia

\begin{tabular}{lccccccc}
\hline Aspek & $\begin{array}{c}\text { Unstandardised } \\
\text { coefficients }\end{array}$ & $\begin{array}{c}\text { Standardised } \\
\text { coefficients }\end{array}$ & $t$ & Sig. & R2 & Sumbangan \\
\cline { 2 - 6 } & B & $\begin{array}{c}\text { Ralat } \\
\text { piawai }\end{array}$ & Beta & & & & \\
\hline $\begin{array}{l}\text { Pembudayaan } \\
\text { nilai melalui } \\
\text { pembelajaran } \\
\text { tidak formal }\end{array}$ & 0.348 & 0.058 & 0.323 & 6.039 & 0.000 & 0.403 & $40.3 \%$ \\
\hline $\begin{array}{l}\text { Penglibatan } \\
\text { penduduk dalam } \\
\text { aktiviti sosial }\end{array}$ & 0.350 & 0.051 & 0.315 & 6.878 & 0.000 & 0.464 & $6.1 \%$ \\
\hline \begin{tabular}{l} 
Pemalar \\
\hline
\end{tabular} & 0.518 & 0.119 & & & & & \\
\hline
\end{tabular}

Dapatan analisis regresi berganda menunjukkan bahawa pembudayaan nilai melalui pembelajaran tidak formal menyumbang sebanyak $40.3 \%$ $(\beta=0.323, t=6.039$, Sig. $=0.000$ dan $\mathrm{R} 2=0.403)$ dan penglibatan penduduk dalam aktiviti sosial menyumbang sebanyak 6.1\% $(\beta=0.315, t=6.878$, Sig. $=0.000$ dan $\mathrm{R} 2=0.464)$. Terdapat kemungkinan baki peratusan yang lain iaitu lebih kurang 53.6\% lagi disumbangkan oleh faktor-faktor lain terhadap amalan nilai-nilai murni yang tidak diambil kira dalam kajian ini.

\section{PERBINCANGAN KAJIAN}

Secara keseluruhannya, dapatan kajian ini telah menunjukkan bahawa tahap penglibatan penduduk di kawasan kejiranan bandar raya pintar Putrajaya dalam aktiviti sosial berada di tahap yang rendah. Situasi ini menunjukkan rata-rata penduduk di kawasan kejiranan kurang meluangkan masa untuk aktiviti sosial. 
Keadaan ini juga menyebabkan nilai-nilai murni tidak dapat berkembang sekaligus sukar diterapkan melalui aktiviti-aktiviti sosial. Faktor ini juga berkemungkinan mempunyai kaitan dengan dapatan kajian lampau yang mendapati bahawa kerenggangan hubungan sosial adalah kerana ketidakseimbangan antara hubungan sesama manusia dengan aktiviti kehidupan termasuklah urusan pekerjaan masing-masing (Tajul Ariffin dan Nor'Aini, 2002). Dapatan kajian ini juga selari dengan kajian yang dijalankan oleh Abd Hadi (2004) yang mendapati punca renggangnya hubungan sosial dalam kalangan masyarakat adalah disebabkan oleh sikap individualistik dan mementingkan diri sendiri. Faktor ini juga merupakan punca utama terhakisnya nilai-nilai murni dalam kalangan keluarga, masyarakat dan di kawasan kejiranan penduduk.

Dalam aspek nilai-nilai murni melalui pembelajaran tidak formal, ia berada pada tahap yang memuaskan iaitu di tahap yang sederhana. Hal ini menunjukkan penduduk-penduduk di kawasan kejiranan Putrajaya belum lagi melibatkan diri secara sepenuhnya dalam program pembelajaran tidak formal yang diadakan. Dapatan ini menunjukkan pembelajaran tidak formal dalam menerapkan nilai-nilai murni yang berkaitan dengan sikap keprihatinan dari segi nasihat, tegur-menegur, kelas-kelas fardhu ain yang dianjurkan di surau dan masjid dan aktiviti-aktiviti keluarga dalam mendidik anak-anak ke arah nilai-nilai murni masih kurang dilaksanakan. Selain daripada itu, program-program tidak formal yang berkaitan dengan belia, kempen, ekspo ke arah meningkatkan kesedaran nilai-nilai murni dalam kalangan masyarakat juga kurang dilaksanakan di kawasan kejiranan Putrajaya. Hasil kajian ini memberi perspektif baru apabila ia dilihat bercanggah dengan kajian lampau yang mengetengahkan kepentingan pembelajaran tidak formal dalam meningkatkan ilmu, kualiti individu dan masyarakat, dan boleh menjamin kesejahteraan yang berterusan (Badu-Nyarko dan Zumapkeh, 2014; Hoppers, 2005).

Data daripada 414 responden menunjukkan bahawa tahap penglibatan sosial, pembelajaran tidak formal dan amalan nilai murni dalam kalangan responden adalah rendah. Majoriti daripada responden lelaki $(57 \%, \mathrm{n}=237)$ mempunyai penglibatan sosial yang lebih rendah berbanding perempuan $(43 \%$, $\mathrm{n}=177)$. Begitu juga dari aspek pembelajaran tidak formal dan amalan nilai apabila majoriti responden lelaki $(57 \%, \mathrm{n}=177)$ mencatatkan tahap pembelajaran tidak formal dan amalan nilai murni yang lebih rendah berbanding perempuan. Sikap tolong-menolong sesama jiran, berinteraksi dengan jiran, dan aktiviti kejiranan dalam kalangan responden Putrajaya adalah rendah. Hal ini menunjukkan tahap mengenali dalam kalangan jiran adalah masih kurang memuaskan. Hasil kajian ini juga selari dengan kajian yang dikemukakan oleh Aiken et al. (1982) di mana sifat ego, jarang tersenyum dan tidak peka pada kawasan sekeliling atau masyarakat di kawasan kejiranan akan menyebabkan renggangnya hubungan sosial dan seterusnya akan menghakis nilai-nilai murni dalam masyarakat. Perkara ini juga ditegaskan dalam kajian Haryati (2007); Selvi dan Katiman (2012) iaitu di antara faktor-faktor yang menyebabkan kurangnya 
penglibatan seseorang individu atau masyarakat dalam aktiviti sosial adalah disebabkan kesukaran dalam menyesuaikan diri dengan persekitaran bandar dan kawasan kejiranan yang baharu dan perkara ini adalah permasalahan yang telah berlaku di kawasan kejiranan Putrajaya.

Dapatan daripada analisis skor min menunjukkan bahawa skor min bagi ketiga-tiga aspek yang dikaji adalah rendah. Skor min bagi penglibatan sosial adalah yang paling rendah $(\mathrm{min}=2.31)$ berbanding dengan tahap dalam pembelajaran tidak formal $(\min =2.57)$ dan amalan nilai murni $(\min =2.73)$. Dapatan kajian ini dapat dirumuskan bahawa amalan nilai-nilai murni dalam kalangan penduduk Putrajaya kurang memuaskan. Maka, usaha perlu dipergiatkan lagi bagi meningkatkan amalan nilai-nilai murni dalam kalangan penduduk Putrajaya seperti aktiviti pemuafakatan dalam pelbagai aktiviti kebajikan, hubungan kejiranan, aktiviti sosial di kawasan kejiranan, tertib dan mengikut aturan serta mengambil berat mengenai masyarakat kejiranan untuk kebaikan. Amalan nilai murni sebegini amat wajar digiatkan kerana Putrajaya merupakan satu simbol kehidupan bandar yang dirancang secara rapi oleh kerajaan Malaysia.

Bagi analisis berdasarkan jantina pula menunjukkan tahap penglibatan aktiviti sosial dalam kalangan penduduk perempuan adalah lebih baik berbanding dengan penduduk lelaki. Keadaan ini adalah disebabkan oleh faktor masa di mana responden lelaki dalam kajian ini bekerjaya $(57 \%, \mathrm{n}=237)$ berbanding kaum perempuan yang kebanyakannya terdiri daripada suri rumah tangga sepenuh masa $(21 \%, \mathrm{n}=86)$. Kajian dilihat selari dengan kajian lampau berkaitan dengan amalan nilai murni yang menunjukkan bahawa kaum perempuan lebih banyak melibatkan dalam aktiviti sosial berbanding kaum lelaki. Hal ini selari dengan kajian yang dilakukan oleh Drakakis (1995); Fatimah, Kartiman dan Zikri (2008) di mana hasil kajian mereka menunjukkan bahawa kaum perempuan lebih mudah berinteraksi dengan masyarakat serta mengamalkan budaya yang lebih mesra dibandingkan dengan kaum lelaki dan perkara ini juga berlaku di kawasan kejiranan Putrajaya.

Berdasarkan analisis ujian- $t$, dapatan kajian menunjukkan tidak terdapat perbezaan yang signifikan nilai-nilai murni melalui pembelajaran tidak formal dalam kalangan penduduk Putrajaya berdasarkan jantina. Dapatan ini menunjukkan bahawa penduduk lelaki dan penduduk perempuan di kawasan Putrajaya mempunyai nilai-nilai murni melalui pembelajaran tidak formal yang hampir sama. Kajian ini bertentangan dengan kajian Presser dan Kishor (1991) di mana hasil kajiannya mendapati kaum perempuan lebih mudah menyertai program tidak formal berbanding kaum lelaki. Selain itu juga, Abdul Razaq, Anisa dan Ahmad (2010) menyatakan kaum perempuan lebih mudah mengamalkan pelbagai nilai dalam kehidupannya berbanding kaum lelaki.

Hasil analisis ujian- $t$ menunjukkan bahawa tidak terdapat perbezaan yang signifikan amalan nilai-nilai murni dalam kalangan penduduk kawasan Putrajaya berdasarkan jantina. Dapatan kajian ini menunjukkan bahawa penduduk lelaki 
dan penduduk perempuan mempunyai amalan nilai-nilai murni yang hampir sama. Walaupun begitu, dari segi min menunjukkan amalan nilai-nilai murni penduduk perempuan lebih tinggi berbanding dengan penduduk lelaki.

Berdasarkan tahap pendidikan pula, didapati golongan yang mempunyai pendidikan yang tinggi iaitu mempunyai ijazah lebih aktif melibatkan diri berbanding daripada mereka mempunyai kelulusan akademik yang agak rendah iaitu di peringkat sijil dan sebagainya. Kajian ini adalah selari dengan kajian yang dilakukan oleh Mohamad Johdi Salleh et al. (2009) yang mendapati pendidikan mempengaruhi pemikiran dan sikap seseorang dan dapatan kajiannya juga menunjukkan mereka yang mempunyai pendidikan yang tinggi mempunyai hubungan tingkah laku yang positif berbanding mereka yang mempunyai tahap pendidikan yang rendah. Perkara ini turut diperkukuhkan oleh kajian Pinto, do Ceu Taveira dan Sa (2012); Adams dan Ryan (2000) yang mendapati individu yang memiliki tahap pendidikan yang lebih baik mempunyai kadar kawalan diri yang tinggi dalam beberapa situasi seperti pengurusan kerja, kepimpinan kerja, pengurusan rumah tangga serta pengurusan komuniti berbanding dengan individu yang mempunyai tahap pendidikan yang rendah. Situasi ini juga berlaku di kawasan kejiranan Putrajaya dan memerlukan satu usaha bagi mengurangkan faktor jurang pendidikan di antara penduduk yang menyebabkan kurangnya penglibatan aktiviti sosial dalam kalangan setempat.

Hasil analisis ujian ANOVA satu hala menunjukkan bahawa terdapat perbezaan yang signifikan terhadap nilai-nilai murni melalui pembelajaran tidak formal dalam kalangan penduduk Putrajaya berdasarkan taraf pendidikan. Dapatan kajian menunjukkan penduduk dengan pendidikan Ijazah/Sarjana/ $\mathrm{PhD}$ mempunyai nilai-nilai murni melalui pembelajaran tidak formal yang lebih tinggi berbanding penduduk dengan taraf pendidikan lainnya. Dapatan ini juga menunjukkan semakin tinggi taraf pendidikan dalam kalangan penduduk kawasan Putrajaya, maka semakin tinggi pula nilai-nilai murni melalui pembelajaran tidak formal yang dijalankan.

Dapatan kajian mendapati pembelajaran tidak formal menunjukkan hubungan yang paling kuat terhadap amalan nilai murni. Dapatan kajian tersebut telah ditegaskan oleh Cross (2001) yang menyatakan bahawa pembelajaran tidak formal adalah satu pendidikan yang dijalankan secara tidak langsung yang mudah difahami iaitu lebih kepada berkongsi pengalaman dan boleh dilaksanakan di pelbagai tempat tanpa memerlukan sistem yang formal seperti sukatan pelajaran, masa dan kemudahan infrastruktur yang sistematik. Dapatan kajian ini selari dengan kajian yang telah dilaksanakan oleh Kennedy, Mok dan Wong (2012); Torney-Purta dan Amadeo (2011); Ringarp dan Rothland (2010) yang mendapati pembelajaran tidak formal boleh memupuk penyertaan sivik termasuklah dalam pembudayaan amalan nilai-nilai murni dalam komuniti setempat.

Justeru dalam perancangan sesebuah bandar dan penempatan perlu mengambil kira nilai-nilai kesejahteraan dalam sesebuah masyarakat. Hal ini jelas disarankan oleh Alfitri, Mohd Mahzan dan Abdul Razaq (2014) yang 
menekankan konsep kejiranan yang terhasil dalam pembentukan bandar Radburn. Ia juga patut menjadi satu asas dalam membentuk masyarakat yang mengamalkan nilai-nilai murni serta kesejahteraan dalam kawasan kejiranan Putrajaya. Manakala konstruk penglibatan penduduk terhadap nilai-nilai murni berdasarkan analisis kolerasi juga menunjukkan hubungan yang signifikan. Hal ini menunjukkan bahawa penglibatan penduduk membantu dalam membentuk kejiranan Putrajaya. Kajian ini selari dengan kajian lampau yang mengatakan komuniti yang menyerlah dan bersatu-padu sentiasa dikaitkan dengan norma saling mempercayai dan bantu-membantu antara jiran (Cicognani, Zani dan Albanesi 2012).

\section{IMPLIKASI KAJIAN}

Kajian ini mendapati bahawa penduduk kawasan bandar raya pintar Putrajaya mempunyai penglibatan aktiviti sosial yang masih rendah. Putrajaya sebagai bandar yang terpelihara dan wajar dicontohi menjadikan dapatan kajian ini sebagai satu masalah yang amat perlu diberi perhatian bagi menangani masalah penglibatan dalam aktiviti sosial yang rendah kerana boleh mengakibatkan citra buruk bagi kawasan Putrajaya. Putrajaya sememangnya sebuah bandar yang serba lengkap dari segi penyediaan kemudahan, landskap, infrastruktur dan pengangkutan. Oleh itu, kemudahan tersebut sepatutnya menjadikan Putrajaya sebagai satu kawasan yang mempunyai aktiviti-aktiviti yang mampu menyokong peningkatan nilai-nilai murni.

Pembelajaran tidak formal merupakan pendidikan yang berkembang melalui interaksi yang berlaku dalam masyarakat dan mendapatkan kemahiran secara sukarela menjadi faktor yang paling kuat bagi usaha untuk meningkatkan nilai-nilai murni dalam kalangan penduduk Putrajaya. Pembelajaran tidak formal menjadi lebih bermakna apabila pengembangan program-programnya lebih memenuhi keperluan dan minat golongan sasaran dan menyediakan pendidikan alternatif bagi menyediakan platform majlis ilmu, latihan kemahiran dan pembinaan keperibadian ke arah pembudayaan dan peningkatan nilai-nilai murni. Pembudayaan amalan nilai-nilai murni yang dimodelkan dalam konsep pembangunan bandar raya pintar Putrajaya memerlukan pendekatan yang holistik bagi mewujudkan masyarakat yang mempunyai jati diri dan berintegriti. Namun, pembudayaan nilai-nilai murni masih kurang memuaskan. Pembudayaan nilainilai murni sepatutnya dapat memberikan contoh kepada penduduk kawasan lainnya di Malaysia ataupun luar negara. Usaha pembudayaan nilai-nilai murni yang perlu ditingkatkan iaitu dari segi pembelajaran tidak formal seperti menjayakan kelas-kelas pengajian agama, memberi teguran kepada anak apabila melakukan kesalahan, kanak-kanak mengikuti kelas pengajian al-Quran dan aktif menyertai aktiviti sosial seperti perjumpaan, majlis keramaian dan sebagainya untuk kebaikan. 
Kedudukan lelaki dan wanita bukan sahaja dibezakan oleh kejadian fizikal mereka, tetapi juga diberikan nilai-nilai yang berbeza oleh budaya. Sungguhpun begitu, dalam pelaksanaan dan pembudayaan amalan nilai-nilai murni tidak terdapat perbezaan yang signifikan berdasarkan jantina. Wanita telah berjaya dalam berbagai bidang, bersaing dengan lelaki, tetapi wanita masih dipengaruhi nilai-nilai budaya tradisi. Selain itu, pengaruh perjuangan wanita di Barat tidak banyak mempengaruhi wanita Melayu. Nilai-nilai yang dipupuk oleh ajaran Islam tetap kukuh dalam mempertahankan prinsip-prinsip yang menentukan kedudukan lelaki dan wanita. Kajian ini dijalankan dengan hanya melibatkan penduduk kawasan Putrajaya bagi menentukan pembudayaan nilainilai murni kawasan kejiranan bandar Putrajaya. Oleh itu, bagi mendapatkan dapatan kajian yang lebih luas diharapkan kajian seterusnya dijalankan ke atas kawasan-kawasan lainnya di Malaysia sehingga dapatan kajian yang terperinci dan maklumat yang lebih luas diperoleh bagi mengetahui pembudayaan nilainilai murni kawasan kejiranan di seluruh negeri di Malaysia.

Dapatan kajian menunjukkan bahawa penduduk yang mempunyai taraf pendidikan Ijazah/Sarjana/PhD mempunyai amalan nilai-nilai murni yang lebih tinggi berbanding dengan penduduk dengan taraf pendidikan SPM/STPM/Sijil/setaraf. Maka, penduduk yang mempunyai taraf pendidikan yang rendah ini perlu melibatkan diri bersama-sama dengan penduduk yang mempunyai pendidikan yang tinggi. Oleh itu, bagi meningkatkan penglibatan golongan yang mempunyai taraf pendidikan yang rendah, aktiviti yang diadakan di kawasan penempatan penduduk Putrajaya harus bersifat menyeluruh tanpa mengira status pendidikan dan ekonomi penduduk dalam pembangunan nilai murni komuniti bandar.

\section{RUMUSAN}

Kajian ini dijalankan bagi mengkaji pembudayaan nilai-nilai murni kawasan bandar raya pintar Putrajaya. Kajian ini mendapati bahawa penglibatan penduduk dalam aktiviti sosial berada pada tahap sederhana. Manakala pelan tindakan amalan nilai-nilai murni, nilai-nilai murni melalui pembelajaran tidak formal, aktiviti-aktiviti penerapan nilai murni dan amalan nilai-nilai murni berada pada tahap sederhana. Perhatian khusus perlu diberikan bagi meningkatkan pembudayaan nilai-nilai murni di kawasan Putrajaya. Cadangan yang diberikan oleh penduduk Putrajaya bagi usaha meningkatkan pembudayaan nilai-nilai murni di antaranya ialah dengan memanfaatkan teknologi dan aktiviti-aktiviti sosial. Pihak pembandaran Putrajaya perlu mengambil berat cadangan-cadangan yang diperoleh dalam kajian ini untuk mengatasi masalah kurangnya pembudayaan nilai-nilai murni di kawasan Putrajaya. 


\section{PENGHARGAAN}

Artikel ini merupakan hasil penyelidikan di bawah Geran Majlis Bekas Wakil Rakyat Malaysia (MUBARAK). Tajuk penyelidikan: Pembangunan Instrumen Patriotisme dan Indeks Toleransi dan Nilai. Kod: GG-2016-008.

\section{RUJUKAN}

Abd Hadi Zakaria. 2004. Ketiadaan reaksi masyarakat terhadap kelakuan anti sosial. The Malaysian Journal of Social Administration 3(1): 71-82.

Abdul Aziz Rahman. 2012. Pendidikan non-formal dan pembudayaan amalan nilai-nilai murni kejiranan di bandar pintar Putrajaya. Master's diss. Universiti Kebangsaan Malaysia.

Abdul Razaq Ahmad, Anisa Saleha and Ahmad Ali Seman. 2010. Kepelbagaian pelajar dan sekolah: Satu kajian kes di Negeri Pahang. Jurnal Pendidikan Malaysia 35(2): 87-95.

Abdul Samad Hadi. 2010. Urbanisasi di Malaysia: Mengaitkan kepelbagaian proses ke bentuk pembandaran. Malaysian Journal of Environmental Management 11(2): $21-31$.

Adams, G. R and B. A. Ryan. 2000. Family relationship, academic environments, and psychosocial development during the university. Journal of Adolescent Research 15: 99-123. http://dx.doi.org/10.1177/0743558400 151006.

Aiken, S. R., T. R. Leinbach, C. H. Leigh and M. R. Moss. 1982. Development and environment in Peninsular Malaysia. Singapura: McGraw-Hill International.

Alfitri, Mohd Mahzan Awang and Abdul Razaq Ahmad. 2014. Culturally-responsive strategies for resolving social conflict in rural community. Mediterranean Journal of Social Social Sciences 5(20): 375-385.

Asmah Ahmad. 2005. Kualiti hidup dan pengurusan persekitaran di Malaysia. In Pengurusan persekitaran 2005. Prosiding Seminar Kebangsaan Pengurusan Perseitaran 2005, Universiti Kebangsaan Malaysia. 4-5 July.

Asyraf Radzwan, Nur Hadi Ibrahim, Mohd Mahzan Awang and Faridah Mydin Kutty. 2014. Kesejahteraan rakyat Malaysia berdasarkan Legatum Prosperity Index. Paper presented at International Social Development Conference, Bayview Hotel Langkawi, Malaysia. 12-13 August.

Badu-Nyarko, S. K. and E. S. K. Zumapkeh. 2014. Effects of non-formal education on the socio-economic development of women in Nadowli District, Ghana. Asian Journal of Humanities and Social Sciences 2(2): 118-132.

Cicognani, E., B. Zani and C. Albanesi. 2012. Sense of community in adolescence. Global Journal of Community Psychology Practice 3(4): 119-125.

Cross, J. A. 2001. Megacities and small towns: Different perspectives on hazard vulnerability. Environmental Hazards 3: 63-80.

Drakakis, S. D. 1995. Third world cities: Sustainable urbanisation I, Urban Studies 32(45): $659-677$.

Expat Insider. 2015. Three years of insights. 7 January. https://www.internations.org/expat-insider/ 
Fatimah Yusof, Kartiman Rostam and Zikri Muhammad. 2008. Bandar berdaya saing visa-vis pembangunan bandar lestari: Suatu wacana tentang pembangunan bandar di Malaysia. Malaysia Journal of Society and Space 4: 85-98.

Ferrans, C. E. 1990. Development of a quality of life index for cancer patients. Oncology Nursing Forum 17(suppl): 15-21.

Gay, L. R. and P. Airasian. 2000. Educational research: Competencies for analysis and application. Upper Saddle River, NJ: Prentice-Hall, Inc.

Grant, M., G. V. Padilla, B. R. Ferrell and M. Rhiner. 1990. Assessment of quality of life with a single instrument. Seminars in Oncology Nursing 6: 260-270. http://dx.doi.org/10.1016/0749-2081(90)90028-4.

Hair, J. F. Jr., R. E. Anderson, R. L. Tatham and W. C. Black. 1998. Multivariate data analysis. 5th ed. Upper Saddle River, NJ: Prentice Hall.

Haryati Shafii. 2007. Persepsi penduduk terhadap tempat tinggal dan kualiti hidup masyarakat bandar. Bangi: Pusat Pengajian Siswazah, Universiti Kebangsaan Malaysia.

Hoppers, W. 2005. Community schools as an educational alternative in Africa: A critique. International Review of Education 51(2-3): 115-137. http://dx.doi.org/10.1007/s11159-005-0445-8.

Jabatan Statistik Malaysia. 2016. Stataistik penduduk Malaysia. https://www.statistics.gov.my/

Jalaluddin Abdul Malek, Abdul Razaq Ahmad and Mohd Mahzan Awang. 2014. Symbiotic relationship between telecentre and lifelong learning for rural community development: A Malaysian experience. TOJET: The Turkish Online Journal of Educational Technology 13(3): 148-156.

Jamil Ahmad. 2002. Pemupukan budaya penyelidikan di kalangan guru di sekolah: Satu penilaian. PhD diss., Universiti Kebangsaan Malaysia.

Johnson, W. 2000. The dictionary of human geography. Oxford: Blackwell Publishing Ltd.

Johnson, G., K. Scholes and R. W. Sexty. 1989. Exploring strategic management. Scarborough, Ontario: Prentice Hall.

Katiman Rostam, Er Ah Choy, Zaini Sakawi, Abdul Rahim Mohd Nor and Aishah@Esah Mohamed. 2010. Pembandaran di pinggir wilayah metropolitan lanjutan Malaysia: Beberapa implikasi terhadap kejiranan dari Lembah Klang-Langat. Malaysian Journal of Society and Space 6(2): 37-50.

Kementerian Kesejahteraan Bandar, Perumahan dan Kerajaan Tempatan. 2014. 16 October. Inisiatif pemutihan kawasan black spot 2013-2015. Siaran media [Rujukan: KPKT/BPK/19/7/4 Klt.43 (36)] .

Kennedy, K. J., M. M. C. Mok and M. Y. W. Wong. 2012. Developing political trust in adolescents: Is there a role for schools? In Psychology of emotions, ed. B. Curtis, New York: Nova Publishers.

Khairani Zakariya @ Abd Hamid. 2012. Kaedah pembangunan akhlak remaja menurut Imam al-Ghazali: Aplikasinya dalam program tarbiah sekolah-sekolah menengah aliran agama berasrama di negeri Kedah, Malaysia. ATIKAN 2(1): 79-94.

Knowles, M. S. 1980. The modern practice of adult education, andragogy versus pedagogy. New York: Cambridge Books. 
Krejcie, R. V. and D. W. Morgan. 1970. Determining sample size for research activities. Educational and Psychological Measurement 30: 607-610.

Masuda, Y. 1990. The information society as post industrial society. Tokyo: Institute for the Information Society.

Meriam, S. B, L. M. Baumgarther and R. S. Caffarella. 2007. Learning in adult hood. 3rd ed. San Francisco: Jossey-Bass.

Mior Khairul Azrin Mior Jamaluddin. 2011. Sistem pendidikan di Malaysia: Dasar, cabaran, dan pelaksanaan ke arah perpaduan nasional. Sosiohumanika 4(1): 3348.

Mohamad Johdi Salleh, Che Noraini Hashim, Ismael Hassanaen and Amir Hasan Dawi. 2009. Status sosio ekonomi dan komitmen ibu bapa terhadap pencapaian pelajar dalam Penilaian Menengah Rendah, Malaysia. 14th International Conference on Education. Bridging words: Making connections in education. Sultan Hassanal Bolkiah Institute of Education Universiti Brunei Darussalam. 21-24 May.

Mohd. Mahzan Awang, Abdul Razaq Ahmad, Nora'asikin Abu Bakar, Sayuti Abd Ghani, Asyraf Nadia Mohd Yunus, Mohd Asrul Hery Ibrahim, Jaya Chitra Ramalu, Che Pee Saad and Mohd Jasmy Abd Rahman. 2013. Students' attitudes and their academic performance in nationhood education. International Education Studies 6(11): 21-28.

Mohd. Majid Konting. 2000. Kaedah penyelidikan pendidikan. 5th ed. Kuala Lumpur: Dewan Bahasa dan Pustaka.

Muzafar Shah Habibullah and A. H. Baharom. 2009. Crime and economic conditions in Malaysia: An ARDL bounds testing approach. Journal of Social Economic 36(11): 1071-1081.

Nik Hassan Shuhami Nik Abdul Rahman and Zuliskandar Ramli. 2011. Penyesuaian manusia kepada kehidupan persekitaran dalam gua zaman prasejarah: Fokas kajian Gua Bewah, Terengganu. PURBA 30: 1-20.

Norhaslina Hassan. 2006. Dinamika masyarakat bandar Malaysia: Ke arah kualiti hidup mapan. Kuala Lumpur: Universiti Malaya Kuala Lumpur.

Pinto, J. C., M. do Ceu Taveira and E. Sa. 2012. Career-self management and entrepreneurship: An experience with $\mathrm{PhD}$ students. Journal of Research in Education \& Psychology 10(3): 985-1010.

Prayinto. 1987. Profesionalisasi konseling dan pendidikan konselor. Jakarta: Depdikbud.

Presser, H. B. and S. Kishor. 1991. Economic development and occupational sex segregation in Puerto Rico: 1950-80. Population and Development Review 17(1): 53-85. http://dx.doi.org/10.2307/1972352.

Ringarp, J. and M. Rothland. 2010. Is the grass always greener? The effect of the PISA results on education debates in Sweden and Germany. European Educational Research Journal 9(3): 422-430. http://dx.doi.org/ 10.2304/eerj.2010.9.3.422.

Sabari Yunus. 2006. Ciri-ciri pembangunan bandar sejahtera. Kuala Lumpur: MIMOS.

Samsuhaizad Samian, Jamaluddin Md. Jahi and Azahan Awang. 2014. Isu perbandaran dan kualiti hidup penduduk bandar. International Journal of the Malay and Civilisation 2(1): 63-75.

Santiago, A. M., G. C. Galster and K. L. S. Pettit. 2003. Neighbourhood crime and scattered-site public housing. Urban Studies 40(11): 2147-2163. http://dx.doi.org/10.1080/0042098032000123222. 
Sardar, Z. 1988. Information in the muslim world: A strategy for the 20th century. London: Mansell Publications Ltd.

Selvi Narayanan and Katiman Rostam. 2012. Impak sosial pembangunan bandar baru Putrajaya terhadap penduduk asal: Kes isi rumah yang dipindahkan ke Taman Permata, Dengkil, Selangor. Geografia: Malaysian Journal of Society and Space 8(4): 44-55.

Shaharudin Idrus, Abdul Samad Hadi, Abdul Hadi Harman Shah and Siti Umira Sulaiman. 2013. Kemunculan Kuala Lumpur sebagai wilayah perbandaran mega diperluas: Menongkah dayahuni dan kelestarian. Persidangan Kebangsaan Geografi dan Alam Sekitar kali ke-4, Tanjung Malim, Perak. 209-217.

Shamsudin Othman. 1993. Pendidikan ke arah masyarakat berfikir. Dewan Masyarakat, Oktober: 20

Simmons, J. 1980. Non formal education \& activity. Boston: Willey \& Sons.

Soja, E. W. 2000. Postmetropolis: Critical studies of cities and regions. Oxford: Blackwell.

Stein, C. and K. C. Parsons, eds. 1989. The writings of Clarence S. Stein: Architect of the planned community. Baltimore, Maryland: Johns Hopkins University Press.

Stewart, A. J. 1976. Arousal of the power motive in women. Journal of Consulting and Clinical Psychology 44: 495-496. http://dx.doi. org/10.1037/0022006X.44.3.495.

Tajul Ariffin Noordin. 2010. Pendidik bina kebenaran universal. Pendidik 69: 55-57.

Tajul Ariffin Nordin and Nor'Aini. 2002. Pendidikan dan pembangunan manusia: Pendekatan bersepadu. Bangi: As-Syabab Media.

Torney-Purta, J. and J.-A. Amadeo. 2011. Participatory niches for emergent citizenship in early adolescence: An international perspective. The ANNALS of the American Academy of Political and Social Science 633: 180-200. http://dx.doi.org/10.1177/0002716210384220.

Unit Pemodenan Tadbiran dan Perancangan Pengurusan Malaysia (MAMPU). 2011. Pelan tindakan pembudayaan amalan nilai-nilai murni bagi bandar raya pintar. Putrajaya: Perbadanan Putrajaya.

United Nation Educational Scientific Organisation. 2015. Promoting learning for the world of work. http://www.unevoc.unesco.org/go.php?q=Non-formal+education \&context $=$

United Nations Development Programme. 2015. Work for human development. Human development report 2015. http://hdr.undp.org/sites/all/themes/hdr_theme/ country-notes/MYS.pdf. (accessed 16 January 2015).

Wan Rozali Hj. Wan Hussin. 2008. Kualiti hidup sosial dan proses pembandaran di Malaysia. Pulau Pinang: Pusat Pendidikan Jarak Jauh USM.

World Health Organisation (WHO). 1948. Constitution of The World Health Organization. Health Conference New York. 19-22 July 1946, signed on 22 July 1946.

Zakaria Stapa, Noranizah Yusuf and Abdul Fatah Shaharudin. 2012. Islam asas pembentukan jati diri bangsa Melayu-Muslim. Jurnal Hadhari Special Edition: $129-141$. 